\title{
The interaction between the largest shareholder and firm performance under the heterogeneity of holding- regulation and intermediary effect of financing constraints ${ }^{1}$
}

\author{
Zhang Lipai ${ }^{1}$; Yu Wenling ${ }^{2}$; Xia Xiqiang \\ (1. School of Business and Management, Shanghai International Studies University, Songjiang District, Shanghai; \\ 2. School of Business, Nanjing University, Gulou District, Nanjing; 3. School of Business, Zhengzhou University, Gaoxin \\ District, Zhengzhou)
}

Abstract: Real estate industry is related to the national economy and people's livelihood, characterized by a high degree of financial intensity. The enterprises in this industry need certain financial ability and large shareholder controlling ability to support their survival. However, due to the multiple adverse impacts of current state policies, banks and private capital, the credit crunch, the sudden decrease in withdrawn funds and the limitation of internal financing, the problem of capital restraint of real estate enterprises has become more and more serious. From the perspective of corporate governance, this paper studies the interaction among financial constraints, ownership concentration and corporate performance under different shareholding states by analyzing the quantitative characteristics of equity structure, and looks for the appropriate range of the largest shareholder holding ratio, which has considered the financial performance and risk. It is found that raising the ownership concentration can effectively ease the financing constraints and improve the performance of enterprises, both of which are significant under the state of high ownership concentration, while the financial constraints play a significant intermediary effect under the State of absolute holding, while in the decentralized state of ownership, there is a significant regulatory effect, and the interaction of the three will be different due to the size of the enterprise.

Keywords: Financial Constraints; Agency Cost; Equity Concentration; Holding Heterogeneity; Real Estate Industry

\section{Research background}

As the cornerstone of corporate governance, the ownership structure provides a realistic basis for the allocation of corporate residual control rights and residual claim rights. The shareholding structure reflects the right to speak and checks and balances of shareholders as owners in corporate reform. Moreover, it is an important part of the "principle-agent" relationship in the reform of the company system. The equity structure adjustment events of listed companies, such as the "True Kungfu Equity Dispute" in 2007, the "Haidilao Equity Resettlement" in 2008, the "Gome Control Power Struggle" in 2010, and the "Vanke Equity Change" in 2015, are all in academic The industry and the industry have aroused widespread and continuous attention, and the rapid changes in the ownership structure will bring unprecedented challenges to corporate governance and even corporate survival. The reform of the ownership structure will bring about changes in the organization and personnel of the enterprise in the short term, and will have an impact on the established management structure; its changes will affect the ability of the enterprise to continue operations in the long term, and adjust the "principle-agent" relationship between owners and operators. The shareholding structure of enterprises has reached a relative equilibrium in the "dynamic game" of concentration and checks and balances of multiple shareholders' shareholdings, and has achieved new changes under external shocks such as market competition changes and the introduction of new economic policies.

\footnotetext{
${ }^{1}$ Fund Projects: National Natural Science Foundation of China, Key project of "Organizational Structure and Collaborative Management of Leading Enterprise Innovation Chains" (71732002); Special project of the National Natural Science Foundation of China, "Impacts and Countermeasures of Major Public Health Emergencies on SMEs" (7204100485); Key Project of the National Natural Science Foundation of China "Research on Organizational Change and Management in a Changing Environment" (71832006).

Author Information: Zhang Lipai (1994-), male, Ph.D. student at Shanghai International Studies University, with research fields of financial technology and corporate finance; Yu Wenling (1988-), male, Ph.D. from Nanjing University, research direction is real estate finance; Xia Xiqiang (1984-), male, Professor of University Business School, research directions are government subsidies and corporate finance.
} 
Under the situation of market and enterprise information asymmetry, ordinary enterprises have external financing constraints, it is difficult to obtain sufficient credit support, and their internal existing financial resources are highly dependent, and the existence of insufficient investment hinders performance improvement; internal entrustment Agency conflicts make it difficult to effectively serve the needs of shareholders and the overall interests of the company. In this situation of "domestic and foreign difficulties", the reform of corporate shareholder equity will provide a way out for companies to improve their performance. A reasonable shareholding structure is a prerequisite for the stable development of an enterprise. Past studies have shown that it has a strong correlation with operating performance - the former determines to a relatively high degree the internal binding force of the enterprise and the degree of performance of the manager's duties, which helps the enterprise operate effectively and improve the market. Value provides institutional guarantees. The concentration or checks and balances of major shareholders' equity is the top priority of equity reform. It determines the rationality of shareholder structure and the right to speak of major shareholders; its degree of equity concentration will significantly change the way and effect of shareholders' exercise of rights, which is formed in all shareholders. Core control, thereby further affecting the company's organizational stability, strategic development model and governance capabilities.

In China, during the past two decades, companies have generally seen a phenomenon of concentration of equity. The concentration of major shareholders (especially the largest shareholder) can significantly optimize the investment and financing decisions and performance of companies within a suitable range; but the previous literature lacks sufficient research on the role of equity trends in different holding states, and also restricts financing The role of "equity concentration-corporate performance" in the transmission process is lack of in-depth discussion. Based on this, the article will examine the effect of corporate equity structure adjustments by studying the "interaction between equity concentration trends, financing constraints, and corporate performance." The impact mechanism of equity changes on performance will be taken from the "supervisory awareness" of major shareholders. Analyze and test the two dimensions of "awareness of supervisory" and "awareness of responsibility". The changes in the management behaviors and methods of major shareholders will have direct or indirect effects on the continuous operation of the company.

Based on the principles of data openness, comparability, and effectiveness, in order to better observe the effect of external financing pressure on corporate equity reform and the impact of equity structure changes on corporate governance, a typical capital-intensive industry - real estate is selected as Focus on the object of analysis. As an important engine of the national economy, the industry is inseparable from ample financial support. But since 2013. Tightening of credit policies-the promulgation of the new "National Five Articles" has led to a serious reduction in funding for housing projects. The average annual interest rate of real estate loans has increased to the range of $15 \%$ to $18 \%$, and the interest rate of private financing exceeds $30 \%$. It is also stricter, thereby suppressing the financial leverage effect. With the triple attack of national policies, capital markets and banks, most real estate companies' turnover growth has slowed down, mergers have intensified, and the industry's concentration has increased. Due to factors such as efficiency and internal control, the trend of equity concentration is more common in real estate companies. Relevant empirical analysis of this type of industry is helpful to investigate the practical significance of the concentration of major shareholders' equity. In addition, according to the characteristics of the real estate industry, find the appropriate scope of holdings for major shareholders to give academics and industry references.

The research layout is as follows: Chapter 2 is a literature review, introducing research progress and remaining shortcomings, and points out the foothold of this research; Chapter 3 proposes relevant theories and hypotheses based on previous research that needs to be improved; Chapter 4 selects samples and agents variables and pre-processed to build a model; Chapter 5 makes empirical analysis of the role of equity concentration on financing constraints and corporate performance differences in sample companies in 
different holding states, and the mediation of financing constraints in the transmission process of "equity concentration-corporate performance" /regulatory role, and the mechanism of the adjustment of the equity structure; Chapter 6 summarizes the conclusions and recommendations, and proposes new research directions.

\section{Literature review}

\section{II.1 Financing constraints and countermeasures}

Financing constraints in a narrow sense refer to business constraints caused by excessively high external financing costs or insufficient credit line allocations, and the total amount of funds cannot match the needs of the company's continuous operation or even investment; while the broad financing constraints refer to internal and external financial constraints. Existing funds caused by restrictions cannot meet normal investment needs. Based on the research of Fazzari et al. (2000), it is defined as: due to the imperfect market, the company is unable to obtain sufficient cash flow, the ability to continue operations is inhibited, and the operating surplus cannot reach the optimal state. With the development of the capital market and enterprises, it has become increasingly difficult for companies to support their further development with endogenous financing, and the importance of external financing has become increasingly prominent; and the existence of financing constraints will significantly limit the investment efficiency of enterprises and reduce their solvency. There was even an unusually low profile.

Research on financing constraints at home and abroad focuses on the impact of financing constraints on business operations and measures, and most of them start from national policies, business operations, and internal control optimization. In terms of impact, there has been extensive evidence supporting that financing constraints have an important or even decisive negative effect on the survival and performance of enterprises. The focus of exploration is financing constraints related to investment activities. For example, Marco and Röell (1998) believe that the more external funds a company needs, the stronger the opportunity for listing. Almeida, et al. (2004) jointly pointed out that the degree of financial constraints of companies has a significant impact on the cash holding policy; Fazzari et al. (2000) analyzed the listed companies in the 20th century and proposed that "the financial constraints of companies will be accompanied by higher cash "Flow sensitivity" and support the rationality of the "investment-cash flow" relationship; Dasgupta, et al. (2011) also confirmed that the degree of corporate financing restriction is positively correlated with investment-cash flow sensitivity.

However, for measures to ease financing constraints, scholars have proposed innovative financing methods, developed a multi-sector DSGE model combined with related industries, and introduced a banking sector with financial liquidity to reduce social financing costs. However, a considerable proportion of enterprises in my country still face severe financing problems. These measures have not penetrated into the level of business management. For example, there are fewer attempts to analyze relevant measures in combination with the quantitative characteristics of the equity structure. The quantitative characteristics are mainly reflected in the degree of equity concentration, such as the proportion of the top three/fifth/ten largest shareholders, which reflects the degree of internal management and supervision of shareholders. However, it is still controversial how to determine the appropriate ratio range of equity concentration.

\section{II.2 The influence of equity concentration on financing constraints and corporate performance}

Ownership concentration is an important indicator to measure corporate equity allocation, organizational structure rationality and internal control. As for whether the concentration of equity should be increased or reduced, existing studies have separately explored the differential effects of major shareholders' equity ratios on the financial status and continuing operations of the company-concentrated on the first type of agency problem (the agency conflict between shareholders and operators), The second type of agency problem (large and small shareholder conflicts of interest) affects the relationship between equity concentration, financing 
constraints, and corporate performance.

According to the principal-agent theory, most scholars point out that equity concentration can improve the corporate governance model and effectively alleviate the first type of agency problem (Nguyen, et al., 2015). Means (2017) points out that the dispersion of capital is inversely proportional to a company's performance, and the concentration of capital can provide powerful and effective control over a company's business. Edwards and Pinkerton (2019) pointed out that those large listed companies have centralized equity all over the world, and for the largest shareholders of most types, increasing equity has a beneficial impact on minority shareholders. Some scholars have found that the concentration of equity can ease financing constraints and improve the performance potential of enterprises. When the shareholding of controlling shareholders is large enough, the possibility of "tunneling behavior" is low (Amp, et al., 2004). Wruck (1989) points out that when announcing private sales, the change of company value is closely related to the change of equity concentration. Deng, et al. (2013) found that equity concentration can effectively improve the innovation ability of enterprises. Meanwhile, compared with companies with multiple owners, companies with single ownership tend to transform research and development into product innovation more effectively, while the latter are usually better at utilizing external knowledge and human capital. Abdelrazaq, et al. (2019) confirmed the positive significance of equity concentration by reducing the "free rider" effect from equity management. Chen, et al. (2009) discussed the mitigation effect of ownership structure measured by differences in controlling shareholder control and cash rights, and found that higher company internationalization is associated with higher level of earnings management, which can reduce the negative impact of internationalization on earnings management by improving company ownership structure. Through the structural equation model, Chen Xing analyzed the relationship between equity concentration and credit constraint in China's A-share listed enterprises and found that equity concentration can effectively solve the principal-agent problem and reduce the credit constraint of enterprises. Greater control over cash management and greater oversight of management reduce the incentive to exploit minority shareholders over their harmful effects (more control over illegitimate private interests). The academic circles also believe that equity concentration can reduce the "first category of agency costs" and make managers tend to choose favorable investment decisions for the company. The "absorption effect" brought by excellent corporate performance in attracting investment can effectively alleviate the financing difficulties of enterprises. If an enterprise achieves equity diversification through public offering, it will still incur some costs, such as increased listing costs and loss of control over the shareholder register (Marco and Roell, 1998).

However, some scholars believe that the concentration of equity has a negative impact on the development of enterprises. They advocate that the corporate equity structure should achieve the effect of mutual supervision and restriction, and that the control rights of enterprises should be decentralized. In order to reduce the influence of ownership concentration on enterprises, the academic circle conducts research mainly from the aspects of financial risk, improvement of internal control system and operation performance. (1) Financial risk level, the academic circle has been based on the analysis of ownership structure concentration on corporate profits, or cash flow of the main link of influence, think that there are risks of profit distribution (caused by abnormal dividend policy, financing risk, policy risk, interest rate risk financing and repayment risk, etc.), investment risk (excessive investment and inadequate investment), operational risk, liquidity surplus and deficiency, Florian (2012) added that private enterprise equity focus on corporate credit availability has significant negative impact; Safiullah and Shamsuddin (2018) investigated the effect of the composition of islamic Sharia Supervisory Board (SSB) on the risk of Islamic Banks, and found that the reduction of equity concentration could effectively reduce the operation and bankruptcy risk of Banks. (2) At the level of internal control, David, et al. (1997) proposed that ownership structure had a significant impact on the change of top management personnel, and had a significant impact on internal monitoring work, which 
was partly due to the impact of ownership structure on external control threats; Edwards and Weichenrieder (2004) showed that the allocation of sufficient equity shares of the second largest shareholder could effectively limit the control of the enterprise by the first largest shareholder. Therefore, the shares of the second largest shareholder guaranteed their right to perform the supervisory role. Amp, et al. (2004), small and medium-sized shareholders is less, if other big shareholders will increase to the interests of minority shareholders encroach on motivation, the major shareholder of shares held more often take self-interest behavior, such as violation of the company's articles of association, misappropriate or transfer of assets, to meet the interests of the individual financial fraud, this is also referred to as "tunneling" (investors with a lower valuation of the equity control of the company's cash dividend and cash holdings, than to have high equity controlled company, it conforms to the tunnel hypothesis). The main forms of corporate major shareholders' encroachment include capital appropriation, related party transactions, guarantee and malicious financing, unfair salary distribution, etc., which are likely to occur after the change of major shareholders' equity, all of which aggravate the information asymmetry between enterprises and external investors. (3) In terms of business performance, Kahn and Winton (1998) found that if external institutions hold certain shares of a company, they can use the company information for trading (speculation) and decide whether to intervene to improve the company's performance. Intervention can increase the value of the existing equity of the institution, but it can only increase the trading profit of the institution if it improves the accuracy of the information of the institution relative to that of the uninformed trader. Cho (1998) found that the ownership structure would affect investment and thus corporate value through the regression of ordinary least square method. Marco and Roell (1998), from the perspective of a company's controlling shareholders, the optimal ownership structure usually involves some kind of decentralization to avoid excessive monitoring by other shareholders.

\section{II.3 Existing research limitations and ideas of this research}

Equity concentration in Chinese enterprises is universal and plays a key role in the investment, financing and performance of enterprises. The centralization of equity can effectively alleviate the conflict of interests between shareholders and managers and reduce the first category of agency costs. The operating condition of a company is also affected by a relatively low degree of equity concentration, which in turn affects its financial indicators and drags down its corporate performance. At present, the literature rarely considers the interaction among the three under different holding states of the largest shareholder. Therefore, the following part takes "the interaction among the three" as the starting point to analyze how the ownership structure of enterprises affects performance and financing.

This paper takes real estate enterprises as an example and USES panel data from WIND and other databases to analyze the relationship between ownership concentration degree and the other two under different shareholding levels of the largest shareholder. The research ideas are as follows.

First, the regulation and mediation of financing constraints are considered in turn. In previous literatures, financing constraints were mainly taken as explained variables to consider how to alleviate financing constraints. However, easing financing constraints is not the ultimate goal, but improving the performance of the company due to healthy financing situation is the ultimate goal. The easing of financing constraints can "unbind" performance improvement and provide material basis for operation and production. Since there are few literatures regarding it as an intermediate factor, its indirect effect is considered. Therefore, this paper takes financing constraints as intermediary and regulatory variables respectively, explores the mode of action of financing constraints based on the path of "ownership concentration -- financing constraints -- enterprise performance", and focuses on observing the specific utility of financing constraints in different shareholding 
states. The model constructed is seen from Figure $1^{2}$.

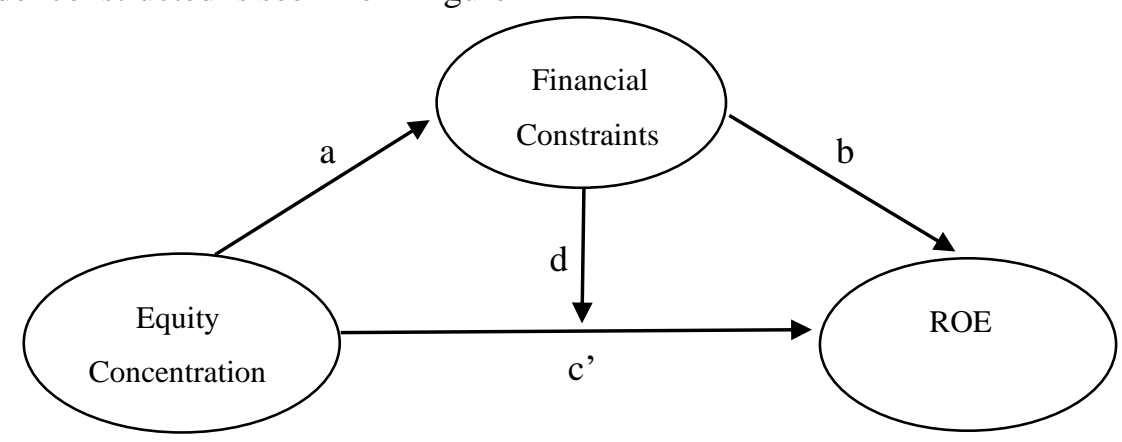

Figure 1 Interactive relationship model of "Equity Structure - Financing Constraints - Enterprise Performance"

Second, the companies are grouped according to the differences in equity status, and the utility differences in the sub-sample groups are observed. This paper compares the interaction between ownership concentration and enterprise performance of the first major shareholder under the condition of differentiation of ownership status, and deeply explores the mechanism of ownership concentration. In addition, in order to guide existing enterprises to improve internal control, the research on the reasonable range of the shareholding ratio of the largest shareholder provides reference for the existing corporate system reform, internal control improvement and sustainable development of enterprises.

\section{Theoretical basis and research hypothesis}

In today's world, the ownership concentration is the organizational form of the ownership structure of most enterprises. The change of equity trend often affects two kinds of agency costs directly or indirectly. The first kind of agency cost is principal-agent contradiction, which mainly arises under the condition of division of labor and asymmetric information. The second kind of agency cost is reflected in the conflict of interests between shareholders, involving "trench defense effect", "tunnel effect" and other ways to obtain private interests through deception, which need to be adjusted by the change of ownership structure.

By strengthening the centralization of equity, major shareholders will have more control and attention to enterprises, which can alleviate financing constraints from the aspects of strengthening supervision, easing credit pressure, and improving investment attraction. First of all, the supervision effect of major shareholders is conducive to improving the corporate governance mechanism, alleviating the conflicts between shareholders and managers, and making managers serve the goal of maximizing shareholders' wealth as much as possible. Under the equity incentive, the sense of responsibility and enthusiasm of major shareholders can be realized by strengthening the daily management. Driven by the sense of ownership, major shareholders will bind their personal interests with the interests of the enterprise, which will promote them to improve the efficiency of capital utilization, reduce the adverse phenomena such as excessive investment, and thus reduce the pressure of capital. So hypothesis H1a is put forward.

H1a: Other conditions remain unchanged. Financing constraints are inversely proportional to ownership concentration.

But there are also studies suggest that the big shareholders centralized phenomenon is not conducive to enterprise information disclosure efficiently, intensifying internal and external information asymmetry and

\footnotetext{
2 After controlling other variables, set the coefficient of equity concentration on financing constraints as 'a'; considering the variable of equity concentration, the coefficient of financing constraints on corporate performance is ' $b$ '; when the financing constraint SA is not controlled, the equity concentration is The effect coefficient on enterprise performance is ' $c$ '; after controlling the SA situation of financing constraints, the effect coefficient of equity concentration on enterprise performance is ' $c$ '; in the transmission process of equity concentration on enterprise performance, the adjusting effect coefficient of financing constraints is ' $\mathrm{d}$ '. The following will focus on whether the corresponding coefficient is significant.
} 
even distorted, make outside investors investment costs, pay for information asymmetry so as to make up the related risk, further makes the rising cost of external financing of the enterprise, into a more difficult financing situation. In addition, with the increase of major shareholders' holdings, their behaviors of seeking personal gains may also occur, resulting in damage to the company's assets. Its typical performance is "self-interested merger and acquisition of major shareholders". This will exacerbate the second type of agency problem. So $\mathrm{H} 1 \mathrm{~b}$ is the opposite hypothesis.

H1b: If other conditions remain unchanged, financing constraints are in direct proportion to equity concentration.

Similarly, the academic circle has found that when the degree of financing constraint is fixed, the increase of equity concentration can effectively reduce the first type of agency cost, ensure the consistent motivation of managers' behavior and maximization of shareholders' equity, and reduce the probability of managers' seeking profits for personal gain. At the same time, equity concentration also promotes the growth of business income, profit and enterprise value by improving operating efficiency. At the same time, with the increase of shareholding, the motivation of major shareholders' occupation will be gradually offset by the increasingly strong sense of "ownership", so it is difficult to "hollowing out" the enterprise value. China Haidilao Group from equal to centralized equity structure adjustment case also verified this conclusion. Therefore, hypothesis H2a is proposed.

H2a: Under the condition of controlling existing financing constraints, the increase of equity concentration degree can effectively improve enterprise performance.

Strengthening the tendency of equity centralization may accompany the phenomenon that major shareholders occupy more equity. Not only emerging markets, but also developed countries with perfect civil law, there are cases reflecting the "tunnel effect", among which the Asian financial crisis in 1997-1998 is a typical one. For performance issues, if the concentration of equity slightly decreases, it can form an effective check among shareholders, make enterprise decision-making more "democratic", play a check and balance role on the minority major shareholders, prevent the operation risk caused by their arbitrary and wrong ideas, and supervise and curb the selfish behavior of major shareholders. It can also encourage minority shareholders to participate more actively in the operation of the company and improve the performance of the enterprise. The decentralized ownership structure effectively restrains the "trench defense effect" and "tunnel effect". If the concentration of equity is reduced, it will be difficult for major shareholders to misappropriate assets and transfer corporate income and profits, thus maintaining the rational allocation of corporate resources. Accordingly, hypothesis $\mathrm{H} 2 \mathrm{~b}$ is proposed.

H2b: Under the condition of controlling existing financing constraints, reducing ownership concentration can significantly improve enterprise performance.

As for the impact of equity concentration on corporate performance, the current research pays little attention to the potential impact of corporate financing constraints. The influence of ownership concentration on corporate performance can be transmitted in three ways :(1) the improvement of ownership concentration brings about changes in corporate governance, which directly affects performance ability; (2) The improvement of equity concentration brings about the change of the financing constraint of intermediary variable, so as to produce the result of "unbinding" or "straitened constraints" for enterprise performance; (3) When the improvement of equity concentration brings about changes in financial performance, financing constraints play a regulating role. As a moderator variable, enterprises with higher financing constraints may have more obvious "action elasticity" and space to reduce constraints, and the conduction utility may be greater. So we have the following hypothesis.

H3: In the transmission process of equity concentration degree to enterprise performance, financing constraints have significant regulating and mediating effects. 


\section{Research sample and design}

\section{IV.1 Sample selection and pretreatment}

This paper attempts to test the above assumptions, disclose the influence mechanism of equity concentration, financing constraints and the performance of real estate companies, and create a reasonable proportion for the largest shareholder. The basic registration information and main financial index data collected in this study were from the WIND database, and the equity concentration index was from the CSMAR database. STATA 16 was used for statistical analysis and test.

The investigated samples are limited to the real estate industry for the following reasons :(1) the real estate industry is a highly capital-intensive industry with a long project investment cycle and high risk. If there are financing constraints, it will directly lead to difficulties such as insufficient investment, operating loss, idle assets, and even threaten the continuous operation. Since the promulgation of restrictive policies such as the new "Five National Principles", real estate enterprises have seen their financing costs rise and their channels become narrower. This is conducive to the observation of financing constraints. (2) Real estate investment has long been regarded as a barometer of China's economic development, and the comprehensive performance of such enterprises will bring significant benefits to the national economy. (3) As the foundation of corporate governance, the ownership structure has a strong correlation with corporate performance; However, the concentration of equity in China's real estate companies is more common. In this highly capital-intensive industry, shareholders can effectively control the company's financial flow and business performance with the increase of shareholding ratio.

A total of 868 data sets of 124 A-share companies listed on the Shanghai and Shenzhen stock exchanges for seven consecutive years from 2012 to 2018 were selected as the original research samples. Samples collected are rejected according to the following criteria :(1) companies with missing or discontinuous material data and abnormal index values; (2) an insolvent company; (3) Cross-listed companies within and outside China.

In order to eliminate the influence of continuous variable extreme value, the outlier Winsor shrinkage was performed (before and after 1\% and 99\% quantile, respectively) to make them equal to corresponding quantile values.

\section{IV.2 Variable setting and model construction}

\section{IV.2.1 Variable settings}

Table 1 Variable setting results

\begin{tabular}{|c|c|c|c|}
\hline Variable types & variable & symbol & Calculation and description \\
\hline Explanatory variables & $\begin{array}{l}\text { Corporate financial } \\
\text { performance }\end{array}$ & $R O E$ & Net profit per year/total final net asset \\
\hline \multirow{2}{*}{ Explanatory variables } & Financing constraints & $S A$ & SAindex $=-0.737 *$ Size $+0.043 *$ Size $^{2}-0.04 *$ Age \\
\hline & Ownership concentration & $O C$ & The proportion of the largest shareholder \\
\hline \multirow{5}{*}{ Control variables } & Degree of equity balance & $O B$ & $\begin{array}{l}\text { The percentage of the top } 10 \text { shareholders/the percentage of the largest } \\
\text { shareholder }-1\end{array}$ \\
\hline & $\begin{array}{l}\text { Establishment of fixed number } \\
\text { of year }\end{array}$ & Age & The number of years which is logarithmically treated \\
\hline & Cash on hand & $\mathrm{CH}$ & The company's annual cash capital/final total assets \\
\hline & The capital structure & $R F A L$ & Total ending liabilities/total final assets \\
\hline & Asset turnover capacity & $T A T$ & Total asset turnover, calculated by current operating income/total assets \\
\hline
\end{tabular}




\begin{tabular}{|c|c|c|c|}
\hline & & & at the end of the period \\
\hline & Fixed assets ratio & FAR & Fixed assets/total assets at the end of the period \\
\hline & Enterprise growth ability & Tobin $Q$ & Market value of the company/replacement cost of assets \\
\hline & Net operating cash flow & $N C F$ & Net operating cash flow/total assets at the end of the period \\
\hline \multirow[b]{2}{*}{ Virtual variable } & The annual & Year & $\begin{array}{l}\text { Dummy variable: if the financial data belongs to a certain year from } \\
2012 \text { to } 2018 \text {, the value of that year is } 1 \text {; otherwise, it is } 0\end{array}$ \\
\hline & Nature of equity & $E N$ & $\begin{array}{l}\text { Dummy variable: it can be divided into } 7 \text { categories according to their } \\
\text { nature: private, central or local state-owned holding, provincial } \\
\text { state-owned holding, collective, foreign capital and others. EN is } 1 \text { if it } \\
\text { belongs to a certain class, otherwise it is } 0\end{array}$ \\
\hline
\end{tabular}

(1) Financing Constraints (SA)

In recent years, most scholars use "investment-cash flow sensitivity", "KZ index" and "credit rating" to measure the degree of financing constraint. However, because this method contains many indicators, when the randomness of sample data is strong, the results will not be accurate enough. In the case of policy changes, enterprises entering a new growth cycle, strategic adjustment, etc., the above indicators will change significantly, making the same indicators not comparable in different stages. Therefore, the SA index is selected to measure financing constraints. The calculation method of SA index is:

$$
\text { SAindex }=-0.737 * \text { Size }+0.043 * \text { Size }^{2}-0.04 * \text { Age }
$$

Size is represented by the value of the total book value of assets. Age is the period from the year of incorporation or merger to the current year.

(2) Corporate Performance (ROE)

From the perspective of shareholders, consider the maximization of shareholder benefit. The return on equity (ROE) is used as a measure and the return on assets (ROA) is used as a robustness test.

(3) Ownership concentration (OC)

Equity concentration reflects the concentration degree of the company's shares among major shareholders. The indicators mainly include the proportion of the largest shareholder (TOP1), the proportion of the top five shareholders (TOP5) and the proportion of the top ten shareholders (TOP10). In most cases, the level of corporate equity concentration is mainly measured by the proportion of the largest shareholder. When the largest shareholder holds more than $50 \%$ of the shares, it has absolute control; The shareholding ratio is between $20 \%$ and $50 \%$, which is in a relatively concentrated holding state; If the first major shareholder holds less than $20 \%$ of the shares, the shareholding dispersion state.

The ownership concentration of the real estate industry is relatively high. From 2012 to 2019, 56.22\% of China's real estate enterprises were in the state of relative holding and $27.79 \%$ were in the state of absolute holding. At the same time, the ratio between the shareholding ratio of the first major shareholder and the sum of the shareholding ratio of the next nine major shareholders is 4.5495 on average. Thus it can be seen that the first major shareholder plays an important and even dominant role in the internal control and operation of the enterprise. Therefore, the shareholding ratio of the largest shareholder is used to measure the level of equity concentration.

(4) Control variable group

(1)The degree of equity checks and balances (OB) and equity concentration is in the opposite of the two indicators, used to measure different shareholders checks and balances. Through sharing supervision by multiple shareholders, negative effects such as "tunneling of major shareholders" caused by excessive concentration of corporate equity can be avoided. Within reason, the value of the company will increase as the 
equity checks and balances increase. However, due to the blind strengthening of equity supervision and checks and balances, there may be power struggles among major shareholders, leading to the decline of corporate decision-making efficiency and corporate value.

Based on "the ratio of top ten shareholders to the largest shareholder -1 ", this paper measures the equity checks and balances, and pays attention to the influence of the remaining nine shareholders on the largest shareholder.

(2)The number of years (Age) of the company is a common control variable, to a certain extent reflects the development of the enterprise, business foundation and the ability to resist financial risks; The cash holding set $(\mathrm{CH})$ and net cash flow from operating activities (NCF) reflect the daily liquidity of the enterprise, and its abundance can reduce the external financing pressure and alleviate the shortage of investment to a certain extent. Asset-liability ratio (RFAL), total asset turnover ratio (TAT), fixed asset ratio (FAR) and enterprise growth ratio (Tobin Q) are commonly used financial indicators, which respectively measure the enterprise's solvency, capital operation ability, production equipment input status and sustainable development ability. They are conventional indicators of performance in multi-dimensional situations.

(5) Dummy variable group

(1)This paper firstly controls the time effect to overcome the disturbance factors which may influence the study due to the time change.

(2) Secondly, because the research samples are limited to the real estate industry in China, the industry effect has been controlled. In view of China's special institutional environment, state-owned enterprises are often restricted by strict operating rules, and the "selfish" behavior of agents is often severely restricted and punished. Therefore, the agency cost is low and the risk of "vacancy" or "offside" is low. And private enterprises often appear "the first kind of agency problem" in the economic transition period. Therefore, this paper will overcome the differences in factors caused by the differences in the nature of the controlling equity.

\section{IV.2.2 Model Constructions}

Based on the research hypothesis, models (1) and (2) are established to test hypothesis 1 and Hypothesis 2:

$$
\begin{aligned}
& S A_{i, t}=a_{0}+a_{1} O C_{i, t}+\text { control }_{i, t-1}+u_{i, t} ; \\
& R O E i, t=\gamma_{0}+\gamma_{1} O C_{i, t}+\gamma_{2} S A_{i, t}+\text { ccontrol }_{i, t-1}+u_{i, t} ;
\end{aligned}
$$

The control variable USES the value of a lag phase to mitigate endogenetic interference.

For hypothesis 3 , the mediating effect and the regulating effect of financing constraints are tested and grouped regression is performed.

\section{Empirical analysis results of the real estate industry}

\section{V.1 Descriptive statistics}

Table 2 Descriptive statistical results of the whole sample group

\begin{tabular}{lrrrrr}
\hline Variable & Obs & Mean & Std.Dev. & Min & Max \\
\hline$R O E$ & 849 & .092 & .111 & -.744 & .65 \\
$S A$ & 849 & 5.303 & 1.912 & .876 & 10.558 \\
$O C$ & .392 & .162 & .1 & .796 \\
$O B$ & 849 & .657 & .678 & .03 & 3.081 \\
Age & 849 & 3.259 & .153 & 2.895 & 3.587 \\
$N C F$ & .01 & .096 & .268 & .271 \\
$R F A L$ & 849 & .646 & .176 & .125 & .92
\end{tabular}




\begin{tabular}{lrrrrr} 
TAT & 849 & .268 & .161 & .02 & .95 \\
Tobin $Q$ & 849 & 1.671 & 1.452 & .84 & 11.69 \\
FAR & 849 & .037 & .065 & 0 & .422 \\
$\mathrm{CH}$ & 849 & .145 & .093 & .021 & .528 \\
\hline
\end{tabular}

In the whole sample group, the mean ROE and standard deviation of corporate performance ROE are 0.092 and 0.111 respectively, indicating that during the sample period studied, Chinese real estate companies as a whole have a positive return on assets, but with certain fluctuations. The mean value and standard deviation of financing constraint SA are 5.303 and 1.912 respectively, and the coefficient of variation is relatively large. OC has little volatility, with a standard deviation of 0.162 and an industry mean value of 0.392 , indicating relatively concentrated ownership. From the perspective of the degree of equity checks and balances, it can be seen that the average proportion of the largest shareholder is 1.657 times that of the following nine major shareholders, which means that the largest shareholder has clear control over the enterprise.

From the control variable group, it can be seen that real estate enterprises generally have a certain number of years of establishment, among which the minimum value after logarithmic treatment is 2.895 (that is, 16.44 years). There are insufficient net operating cash flow (mean value is only 0.01 ), high operating debt ratio (mean value is 0.646 ) and insufficient turnover capacity (mean value is only 0.268). However, the current growth indicators show a good average of 1.671, reaching the peak of 11.69, which will encourage companies to continue to increase investment spending.

For the description of the key indicators of the sample group, it should also be divided into: equity allocation group, equity concentration group and equity highly concentration group according to the situation of equity concentration, so as to compare whether there is a difference between the key indicators.

Table 2-1 Descriptive statistical results of key indicators in the subsample group

\begin{tabular}{|c|c|c|c|c|c|}
\hline Variable & Obs & Mean & Std.Dev. & Min & Max \\
\hline \multicolumn{6}{|c|}{ Equity diversification group } \\
\hline$R O E$ & 117 & .058 & .077 & -.154 & .328 \\
\hline$S A$ & 117 & 4.523 & 2.274 & .876 & 10.558 \\
\hline$O C$ & 117 & .159 & .032 & .1 & .2 \\
\hline Tobin $Q$ & 117 & 2.598 & 2.932 & .84 & 11.69 \\
\hline \multicolumn{6}{|c|}{ Relatively concentrated group } \\
\hline$R O E$ & 496 & .085 & .118 & -.744 & .65 \\
\hline$S A$ & 496 & 5.292 & 1.906 & .876 & 10.558 \\
\hline$O C$ & 496 & .351 & .09 & .2 & .5 \\
\hline Tobin $Q$ & 496 & 1.574 & 1.12 & .84 & 11.69 \\
\hline \multicolumn{6}{|c|}{ Highly concentrated group } \\
\hline$R O E$ & 236 & 124 & .102 & -.366 & .514 \\
\hline$S A$ & 236 & 5.713 & 1.587 & 2.982 & 10.003 \\
\hline$O C$ & 236 & .593 & .08 & .5 & .796 \\
\hline Tobin $Q$ & 236 & 1.417 & .457 & .84 & 3.37 \\
\hline
\end{tabular}

As shown in Table 2-1, when the equity of an enterprise is relatively dispersed, the average return on assets (ROA) of 5.8\% is significantly lower than the industry average, with a gap of $2.7 \%$ and $6.6 \%$, respectively, compared with the relatively concentrated group and the highly concentrated group. At the same time, its SA mean is the lowest, that is, the degree of financing constraint is the highest. In the equity concentration index, the largest shareholder holds most of the shares, and the mean value of the three sample groups is in stepped form -- 15.9\%, 35.1\%, and 59.3\%. In Tobin Q, an indicator representing growth, the mean value of the equity dispersion group was 2.598 , much higher than that of the other two groups (1.574, 1.417). Therefore, it is preliminarily concluded that there may be a positive relationship among equity 
concentration, financing constraint and operating performance. However, large shareholders with large holdings may hinder the long-term development of enterprises.

\section{V.2 Correlation analysis}

Table 3 Correlation analysis and test

\begin{tabular}{llllllllllll}
\hline Variables & (1) & (2) & (3) & (4) & (5) & (6) & (7) & (8) & (9) & (10) & (11) \\
\hline (1) $R O E$ & 1.000 & & & & & & & & & & \\
(2) $S A$ & $0.301^{*}$ & 1.000 & & & & & & & & & \\
(3) OC & $0.200^{*}$ & $0.186^{*}$ & 1.000 & & & & & & & & \\
(4) OB & -0.018 & $0.092^{*}$ & $-0.653^{*}$ & 1.000 & & & & & & & \\
(5) Age & $0.107^{*}$ & -0.055 & $-0.133^{*}$ & $0.129^{*}$ & 1.000 & & & & & & \\
(6) NCF & $0.102^{*}$ & -0.059 & -0.005 & -0.002 & 0.004 & 1.000 & & & & & \\
(7) RFA & $0.169^{*}$ & $0.616^{*}$ & $0.196^{*}$ & 0.005 & 0.001 & $-0.093^{*}$ & 1.000 & & & & \\
(8) TAT & $0.178^{*}$ & $-0.130^{*}$ & -0.027 & -0.013 & -0.031 & $0.235^{*}$ & -0.003 & 1.000 & & & \\
(9) Tobin $Q$ & $-0.155^{*}$ & $-0.503^{*}$ & $-0.182^{*}$ & $0.146^{*}$ & $0.094^{*}$ & -0.011 & $-0.404^{*}$ & -0.003 & 1.000 & & \\
(10) FAR & $-0.111^{*}$ & $-0.195^{*}$ & -0.033 & $-0.133^{*}$ & $-0.089^{*}$ & $0.087^{*}$ & $-0.122^{*}$ & $0.261^{*}$ & 0.049 & 1.000 & \\
(11) CH & $0.117^{*}$ & $-0.239^{*}$ & 0.060 & $-0.070^{*}$ & 0.067 & $0.251^{*}$ & $-0.346^{*}$ & $0.144^{*}$ & $0.248^{*}$ & $-0.077^{*}$ & 1.000 \\
\hline
\end{tabular}

* shows significance at the .05 level.

As shown in Table 3, the interpretation of SA and OC's financing restrictions is closely related to ROE's performance, with correlation coefficients of 0.301 and 0.200 respectively. At the same time, the control variables that reflect the financial ability of enterprises are also significantly related to ROE, which proves the effectiveness of the selection of control variables.

OC, OB and SA are highly correlated, indicating that adjusting the holding status may have an effect on easing financing constraints. At the same time, we found that $\mathrm{OC}$ variables were significantly correlated with Age, RFAL, Tobin Q, etc., thus proving the significance of adjusting equity structure and corporate finance.

Among the control variables, the correlation between RFAL, Tobin Q and SA reached 0.616 and -0.503 respectively (both significant at the $5 \%$ probability level), indicating that capital structure is strongly correlated with growth and financing constraints. In the above analysis, the absolute value of correlation coefficients does not exceed 0.5 , thus overcoming the problem of multiple collinearity.

\section{V.3 Multiple regression results}

\section{V.3.1 Multiple regression results-Assumption 1 and Assumption 2}

In hypothesis 1, with financing constraint SA as the explained variable, after main regression, it is divided into :(1) equity dispersion group (no more than 20\%) according to the proportion of shares held by the largest shareholder; (2) Relatively concentrated group of equity (between 20\% and 50\%); (3) Highly concentrated group of shares (over 50\%). In Hypothesis 2, the enterprise performance ROE is taken as the explained variable, and regression is performed according to the same grouping standard as hypothesis 1.

The regression of hypothesis 1 shows that the SA index can be significantly increased by increasing the ownership concentration (at the $1 \%$ probability level), that is, the financing constraint can be effectively reduced, and the corresponding coefficient value is 2.503 . In the grouping regression, the utility of the decentralized equity group was not significant, while that of the relatively centralized equity group and the highly centralized equity group was significant under the probability of 5\% and $10 \%$ respectively, and the corresponding coefficient values were 3.374 and 3.077 respectively. In the state of equity dispersion, the motivation and effect of marginal encroachment on the shareholding of the largest shareholder are generally more obvious, which will result in interest infringement and resource deprivation to other shareholders, thus restricting the positive effect of increasing equity concentration. However, in the sample group where major shareholders occupy an important or even dominant position, their self-interested behavior and marginal motivation are relatively insufficient, so that the positive utility of increasing ownership concentration is greater than the negative utility, thus effectively reducing financing constraints. The essence of the change of 
equity trend is the dynamic balance and game between the "selfish" behavior and the "overall interests of the enterprise" under the goal of maximizing the shareholders' finance.

Through hypothesis 2 regression, it is found that an increase in SA index (i.e., a reduction in financing constraints) can improve ROE, both significantly at the $1 \%$ level. In the main regression, increasing the equity concentration degree OC can significantly improve ROE, and the corresponding coefficient value is 0.120 . However, in the grouping regression, the beta coefficient of OC on ROE was not obvious in both the relative equity concentration group and the equity dispersion group. Only in the highly concentrated equity group could ROE be effectively improved, with a probability level of 5\%. In the absolute holding case, brought by the major shareholders holdings increase supervision, operation efficiency improvement, cost reduction and so on positive impact, will be "moat defensive effect" empty "tunneling" behavior offset, and in the condition of absolute holding big shareholders occupy effect is reduced, under the "hero consciousness" housekeeper effect, so as to improve business performance.

Table 4 models (1) and (2): multiple regression results

\begin{tabular}{|c|c|c|c|c|c|c|c|c|}
\hline Variables & $S A$ & $\begin{array}{c}S A \\
(<0.2)\end{array}$ & $\begin{array}{c}S A \\
(0.2-0.5)\end{array}$ & $\begin{array}{c}S A \\
(>0.5)\end{array}$ & $R O E$ & $\begin{array}{l}R O E \\
(<0.2)\end{array}$ & $\begin{array}{c}R O E \\
(0.2-0.5)\end{array}$ & $\begin{array}{l}R O E \\
(>0.5)\end{array}$ \\
\hline \multirow[t]{2}{*}{$S A$} & & & & & $0.024^{* * *}$ & $0.015^{* * *}$ & $0.026^{* * *}$ & $0.034^{* * *}$ \\
\hline & & & & & $(6.04)$ & (4.64) & $(5.02)$ & $(4.07)$ \\
\hline \multirow[t]{2}{*}{$O C$} & $2.503^{* * *}$ & 2.635 & $3.374^{* *}$ & $3.077^{*}$ & $0.120^{* * *}$ & 0.216 & 0.048 & $0.144^{* *}$ \\
\hline & $(4.08)$ & $(0.37)$ & $(2.54)$ & (1.77) & $(3.70)$ & $(0.92)$ & $(0.63)$ & $(2.51)$ \\
\hline \multirow[t]{2}{*}{$O B$} & $0.669^{* * *}$ & 0.274 & $0.747^{* * * *}$ & 0.508 & 0.008 & 0.013 & 0.001 & 0.010 \\
\hline & $(4.27)$ & $(1.00)$ & $(3.25)$ & $(0.38)$ & $(0.89)$ & $(1.27)$ & $(0.09)$ & $(0.19)$ \\
\hline \multirow[t]{2}{*}{ Age } & -0.536 & $4.674^{* *}$ & -1.245 & -0.397 & $0.093^{* * *}$ & 0.053 & $0.153^{* * *}$ & 0.007 \\
\hline & $(-0.72)$ & (1.83) & $(-1.52)$ & $(-0.47)$ & (3.01) & $(1.52)$ & (3.69) & $(0.13)$ \\
\hline \multirow[t]{2}{*}{$N C F$} & -0.144 & 0.467 & 0.014 & 0.648 & $0.072^{*}$ & 0.058 & 0.065 & 0.001 \\
\hline & $(-0.31)$ & $(0.40)$ & $(0.02)$ & $(0.70)$ & $(1.80)$ & $(0.67)$ & (1.11) & $(0.01)$ \\
\hline \multirow[t]{2}{*}{ RFAL } & $4.384^{* * *}$ & $3.264^{* *}$ & $4.527^{* * * *}$ & $3.628^{* * *}$ & -0.036 & -0.016 & -0.064 & 0.026 \\
\hline & $(8.20)$ & $(2.04)$ & (7.15) & (3.97) & $(-0.94)$ & $(-0.35)$ & $(-1.16)$ & $(0.44)$ \\
\hline \multirow[t]{2}{*}{$T A T$} & $-0.889^{*}$ & 0.077 & -0.622 & -1.454 & $0.129^{* * *}$ & 0.038 & $0.165^{* * *}$ & $0.182^{* *}$ \\
\hline & $(-1.67)$ & $(0.05)$ & $(1.03)$ & $(-1.52)$ & (3.77) & $(0.96)$ & (3.95) & $(2.43)$ \\
\hline \multirow[t]{2}{*}{ Tobin $Q$} & $-0.459^{* * *}$ & $-0.55^{* * *}$ & $-0.505^{* * *}$ & $-0.763^{* *}$ & 0.001 & -0.003 & 0.005 & $0.052^{* * *}$ \\
\hline & $(-5.44)$ & $(-4.91)$ & $(-5.11)$ & $(-2.36)$ & $(0.23)$ & $(-0.84)$ & $(0.51)$ & (2.94) \\
\hline \multirow[t]{2}{*}{$F A R$} & $-2.675^{* *}$ & $-7.18^{* * *}$ & $-3.360^{* *}$ & 1.687 & -0.111 & 0.004 & -0.194 & -0.089 \\
\hline & $(-2.29)$ & $(-3.17)$ & $(-2.24)$ & $(0.34)$ & $(-1.22)$ & $(0.05)$ & $(-0.94)$ & $(-1.04)$ \\
\hline \multirow[t]{2}{*}{$\mathrm{CH}$} & -0.699 & 1.515 & -0.872 & -1.055 & $0.175^{* * *}$ & 0.034 & $0.203^{* * *}$ & $0.211^{* *}$ \\
\hline & $(-0.95)$ & $(0.85)$ & $(-1.00)$ & $(-0.85)$ & (3.56) & $(0.32)$ & $(2.92)$ & (2.68) \\
\hline \multirow[t]{2}{*}{ Constant } & $4.352^{*}$ & -10.16 & $6.448^{* *}$ & $5.315^{*}$ & $-0.431^{* * *}$ & $-0.249^{* *}$ & $-0.554^{* * *}$ & $-0.423^{* *}$ \\
\hline & (1.87) & $(-1.26)$ & $(2.32)$ & (1.97) & $(-4.04)$ & $(-2.48)$ & $(-3.74)$ & $(-2.03)$ \\
\hline Firm & Control & Control & Control & Control & Control & Control & Control & Control \\
\hline Industry & Control & Control & Control & Control & Control & Control & Control & Control \\
\hline Year & Control & Control & Control & Control & Control & Control & Control & Control \\
\hline Observations & 849 & 117 & 496 & 236 & 849 & 117 & 496 & 236 \\
\hline R-squared & 0.588 & 0.758 & 0.600 & 0.583 & 0.275 & 0.551 & 0.262 & 0.335 \\
\hline
\end{tabular}




\begin{tabular}{c|c|c|c|c|c|c|c|cc}
\hline $\mathrm{F}$ & 25.96 & 15.06 & 15.85 & 14.24 & 10.65 & 5.56 & 8.30 & 4.87 \\
\hline P-Value & 0.000 & 0.000 & 0.000 & 0.000 & 0.000 & 0.000 & 0.000 & 0.000 \\
\hline
\end{tabular}

Note: In brackets are t statistics, $* * * \mathrm{P}<0.01, * * \mathrm{P}<0.05, * \mathrm{P}<0.1$.

\section{V.3.2 Multiple regression results-Assumption 3}

As for the role of financing constraint between "ownership concentration" and "enterprise performance", the mediating effect and the regulating effect are considered respectively.

(1) Mediating effect

As shown in Figure 1, after controlling other variables, set the equity concentration degree as the constraint coefficient of financing a; After considering the ownership concentration degree, the effect coefficient of financing constraint on enterprise performance is $\mathrm{B}$; When financing constraints are not controlled, the coefficient of equity concentration on enterprise performance is C. After controlling the financing constraints, the coefficient of equity concentration on enterprise performance is $\mathrm{C}$ '. According to the holding rate of the largest shareholder, it is grouped, as shown in Table 5.

Table 5 Regression results of mediating effect

\begin{tabular}{|c|c|c|c|c|c|c|}
\hline Mediating effect assessment & $\begin{array}{c}\text { Total effect } \\
\text { (c) }\end{array}$ & $\begin{array}{c}\text { Direct effect } \\
\text { (c') }\end{array}$ & Indirect effect (ab) & A & $\mathrm{b}$ & Note \\
\hline \multicolumn{7}{|c|}{ Total state of equity (full sample) } \\
\hline Coefficient $\beta$ & 0.181 & 0.120 & 0.06 & 2.50 & 0.024 & \multirow{3}{*}{$\begin{array}{l}\text { The indirect effect } \\
\text { coefficient column is the } \\
\text { product of the estimated } \\
\text { values of A and B, whose } \\
\text { significance depends on } \\
\text { the significance of A and } \\
\text { B. }\end{array}$} \\
\hline T-value & 4.95 & 3.70 & / & 4.08 & 6.05 & \\
\hline Significance & 0.000 & 0.000 & / & 0.000 & 0.000 & \\
\hline \multicolumn{7}{|c|}{ State of equity dispersion: shareholding ratio of the largest shareholder is less than $20 \%$ (subsample) } \\
\hline Coefficient $\beta$ & 0.256 & 0.216 & 0.040 & 2.635 & 0.015 & \multirow{3}{*}{$\begin{array}{l}\text { If the total effect } \\
\qquad \mathrm{C} \text { is not } \\
\text { significant, the } \\
\text { analysis of } \\
\text { mediating effect } \\
\text { will be stopped. }\end{array}$} \\
\hline T-value & 0.91 & 0.92 & I & 0.37 & 4.64 & \\
\hline Significance & 0.370 & 0.369 & I & 0.718 & 0.000 & \\
\hline \multicolumn{7}{|c|}{ Relative concentration of equity: the shareholding ratio of the largest shareholder is between $20 \%$ and $50 \%$ (subsample) } \\
\hline Coefficient $\beta$ & 0.136 & 0.048 & 0.088 & 3.373 & 0.026 & \multirow{3}{*}{$\begin{array}{l}\text { If the total effect } \\
\qquad \mathrm{C} \text { is not } \\
\text { significant, the } \\
\text { analysis of } \\
\text { mediating effect } \\
\text { will be stopped. }\end{array}$} \\
\hline T-value & 1.64 & 0.63 & I & 2.54 & 5.02 & \\
\hline Significance & 0.104 & 0.532 & I & 0.013 & 0.000 & \\
\hline \multicolumn{7}{|c|}{ Highly concentrated equity: the largest shareholder holds more than $50 \%$ shares (subsample) } \\
\hline Coefficient $\beta$ & 0.250 & 0.144 & 0.105 & 3.078 & 0.034 & \\
\hline T-value & 2.64 & 1.78 & I & 1.77 & 4.07 & \\
\hline Significance & 0.011 & 0.081 & I & 0.082 & 0.000 & \\
\hline
\end{tabular}

In the total sample, the intermediation effect of financing constraints is significant, and the proportion in the total impact is $0.06 / 0.181=0.33$. However, the effect was not significant in the decentralized group and the relatively centralized group. In the highly concentrated equity group, the impact of financing constraints is 
significant, and the proportion of total impact is $0.105 / 0.250=0.42$. It can be seen that under the premise of absolute holding, the intermediation effect of financing constraint is highly significant. Under the absolute controlling status of "I am the majority", the increase of ownership concentration will improve the control power of major shareholders over the management and give full play to the "supervision effect of major shareholders" rather than the "expropriation effect". As the overall interests of the enterprise are gradually consistent with the interests of major shareholders, major shareholders will pay more attention to financial distribution and organizational management, so as to enhance cash holdings, curb financing constraints, and realize "shareholder wealth maximization".

(2) Regulatory effect

In order to avoid the multicollinearity problem, all data indicators were centralized and then the two models were regressed respectively. Compared with Model 1, both model 2 take enterprise performance as the explained variable, and the explanatory variable and control variable remain unchanged. However, model 2 adds the interaction item index of SA and OC after standardization. It can be seen from Table 6 that the change in $\mathrm{R}$ square is 0.004 , and its significant change in $\mathrm{F}$ is 0.034 , which is highly significant under the probability of $5 \%$, thus confirming the existence of the regulatory effect.

Table 6 Moderating effect test results - based on R2

\begin{tabular}{|c|c|c|c|c|c|c|c|c|}
\hline Model & $\mathrm{R}$ & $\mathrm{R}^{2}$ & Adjusted_R ${ }^{2}$ & $\begin{array}{c}\text { Variation } \\
\text { of } \\
\mathrm{R}^{2}\end{array}$ & $\begin{array}{l}\text { Variation } \\
\text { of } \\
\text { F-statistics }\end{array}$ & $\begin{array}{l}\text { Degrees of } \\
\text { freedom } 1\end{array}$ & $\begin{array}{l}\text { Degrees } \\
\text { of } \\
\text { freedom } 2\end{array}$ & $\begin{array}{l}\text { Change in } \\
\text { significance } \\
\text { of } F\end{array}$ \\
\hline 1 & .525 & .275 & .256 & .275 & .275 & 22 & 826 & .000 \\
\hline 2 & .529 & .279 & .259 & .004 & 4.492 & 1 & 825 & .034 \\
\hline
\end{tabular}

In Table 7, it can be seen from grouping that, after the addition of interaction terms, the interpretation strength of the equation becomes stronger, increasing from 0.256 to 0.259 , and the interaction term coefficient is positive, which is significant at $5 \%$ probability, indicating that the mitigation of financing constraints can play a positive regulatory role, and it mainly plays a significant role in the equity dispersion group. According to descriptive statistics, the financing constraint of the equity dispersed group is much greater than that of the other two groups, and it has more obvious "action elasticity" and reduced constraint space. If it is alleviated, the conduction utility may be greater.

Table 7 Moderating effect test results - Based on multiple regression results

\begin{tabular}{|c|c|c|c|c|c|}
\hline Variables & $R O E \_Z$ & $R O E \_Z$ & $R O E \_Z(<0.2)$ & $\begin{array}{l}R O E \_Z \\
(0.2-0.5)\end{array}$ & $\begin{array}{c}\text { ROE_Z } \\
(>0.5)\end{array}$ \\
\hline \multirow[t]{2}{*}{$S A \_Z$} & $0.420^{* * *}$ & $0.421^{* * *}$ & $1.150^{* *}$ & $0.461^{* * *}$ & $0.483^{* *}$ \\
\hline & (9.102) & $(9.140)$ & $(2.24)$ & $(6.81)$ & $(2.12)$ \\
\hline \multirow[t]{2}{*}{$O C \_Z$} & $0.175^{* * *}$ & $0.184^{* * *}$ & 0.486 & 0.098 & 0.193 \\
\hline & (4.102) & $(4.296)$ & $(0.191)$ & $(0.97)$ & (1.33) \\
\hline \multirow[t]{2}{*}{$S A \_Z * O C \_Z$} & & $0.073^{* *}$ & $0.581^{* *}$ & 0.101 & 0.082 \\
\hline & & $(2.119)$ & $(2.21)$ & $(1.09)$ & $(0.52)$ \\
\hline \multirow[t]{2}{*}{$O B \_Z$} & 0.051 & 0.069 & 0.061 & 0.032 & 0.064 \\
\hline & (1.158) & $(1.556)$ & $(1.17)$ & $(0.42)$ & $(0.19)$ \\
\hline \multirow[t]{2}{*}{ Age_Z } & $0.128^{* * *}$ & $0.133^{* * *}$ & 0.063 & $0.208^{* * *}$ & 0.010 \\
\hline & (4.164) & $(4.320)$ & $(0.77)$ & $(4.46)$ & $(0.19)$ \\
\hline \multirow[t]{2}{*}{$N C F \_Z$} & $0.062^{*}$ & $0.064^{*}$ & 0.058 & 0.059 & 0.005 \\
\hline & (1.894) & (1.957) & $(1.02)$ & $(1.26)$ & $(0.08)$ \\
\hline$R F A L \_Z$ & -0.057 & -0.059 & -0.076 & $-0.100^{*}$ & 0.035 \\
\hline
\end{tabular}




\begin{tabular}{|c|c|c|c|c|c|}
\hline & $(-1.405)$ & $(-1.468)$ & $(-0.98)$ & $(-1.71)$ & $(0.39)$ \\
\hline \multirow[t]{2}{*}{$T A T \_Z$} & $0.187^{* * *}$ & $0.197^{* * *}$ & 0.071 & $0.247^{* * * *}$ & $0.264^{* * *}$ \\
\hline & $(5.642)$ & (5.888) & (1.35) & $(5.35)$ & (3.13) \\
\hline \multirow[t]{2}{*}{ Tobin $Q \_Z$} & 0.014 & -0.013 & -0.060 & 0.057 & $0.679^{* * * *}$ \\
\hline & $(0.371)$ & $(-0.314)$ & $(-1.10)$ & $(0.80)$ & $(2.90)$ \\
\hline \multirow[t]{2}{*}{ FAR_Z } & $-0.065^{*}$ & $-0.071^{* *}$ & -0.014 & $-0.120^{* *}$ & -0.048 \\
\hline & $(-1.865)$ & $(-2.041)$ & $(-0.26)$ & $(-2.14)$ & $(-0.53)$ \\
\hline \multirow[t]{2}{*}{$\mathrm{CH} \_\mathrm{Z}$} & $0.147^{* * *}$ & $0.151^{* * *}$ & 0.070 & $0.166^{* * * *}$ & $0.172^{* * * *}$ \\
\hline & $(4.183)$ & (4.318) & $(0.86)$ & $(3.18)$ & (2.68) \\
\hline \multirow[t]{2}{*}{ Constant } & -0.097 & -0.134 & 0.692 & 0.223 & -0.511 \\
\hline & $(-1.060)$ & $(-1.447)$ & $(1.13)$ & $(1.05)$ & $(-1.34)$ \\
\hline Firm & Control & Control & Control & Control & Control \\
\hline Industry & Control & Control & Control & Control & Control \\
\hline Year & Control & Control & Control & Control & Control \\
\hline Observations & 849 & 849 & 117 & 496 & 236 \\
\hline R-squared & 0.256 & 0.259 & 0.464 & 0.2285 & 0.2634 \\
\hline $\mathrm{F}$ & 10.647 & 13.441 & 5.56 & 7.37 & 4.65 \\
\hline P-Value & 0.000 & 0.000 & 0.000 & 0.000 & 0.000 \\
\hline
\end{tabular}

\section{V.3.3 Robustness check}

To enhance the credibility of the study, the following tests were conducted.

Table 8 Robustness test results

\begin{tabular}{c|c|c|c|c|c|c|c|c}
\hline Variables & $S A(1)$ & $S A(2)$ & $S A(3)$ & $R O A(1)$ & $R O A(2)$ & $R O A(3)$ & $R O A \_Z$ & $R O A \_Z$ \\
\hline$O C$ & $2.574^{* * *}$ & $0.841^{* * *}$ & $1.883^{*}$ & $0.043^{* * *}$ & $0.0435^{*}$ & $0.0477^{* *}$ & $0.452^{* * *}$ & $0.251^{*}$ \\
\hline$S A$ & & & & $0.006^{* * *}$ & $0.007^{* * *}$ & $0.006^{* * *}$ & $0.162^{* * *}$ & $0.413^{* *}$ \\
\hline$S A^{*} O C$ & & & & & & & $0.078^{* *}$ & $0.099^{*}$ \\
\hline Control Variable & Control & Control & Control & Control & Control & Control & Control & Control \\
\hline Firm & Control & Control & Control & Control & Control & Control & Control & Control \\
\hline Industry & Control & Control & Control & Control & Control & Control & Control & Control \\
\hline Year & Control & Control & Control & Control & Control & Control & Control & Control \\
\hline Observations & 849 & 849 & 732 & 849 & 236 & 849 & 849 & 282 \\
\hline P-Value & 0.000 & 0.000 & 0.000 & 0.000 & 0.000 & 0.000 & 0.000 & 0.000 \\
\hline
\end{tabular}

(1) In the test of the relationship between financing constraints and equity concentration. Considering the limitations of the selected growth indicators (which cannot accurately reflect the market price information, and have lag time and price deviation), the control variable Tobin $\mathrm{Q}$ was changed into dynamic price-earnings ratio $(\mathrm{PE})$, namely the ratio between equity price and annual after-tax profit per share. After Winsor tail reduction, the beta coefficient of $\mathrm{OC}$ was 2.574 and the $\mathrm{P}$ value was 0.000 , which were still proportional and highly significant. On the basis of these, the fixed effect of individual enterprises was added into the equations, and OC coefficient was still positive and highly significant. On the basis of these, the samples are limited to the relatively concentrated group and the highly concentrated group, because these two groups are significant in the empirical study of the relationship between them. The test results show that the coefficient is 1.883 , which is significant under $10 \%$ probability.

(2) On the premise of controlling financing constraints, when studying the relationship between equity 
concentration and enterprise performance. Multi-dimensional analysis is used to change the indicators of corporate performance from ROE to ROA, and the control variable Tobin Q is further changed into dynamic price-earnings ratio $(\mathrm{PE})$, which is applied to the regression detection of interactive relations. Results In the positive relationship test between ownership concentration and financial performance, OC beta coefficient was 0.043 and $\mathrm{P}$ value was 0.000 . On the basis of, the sample group of the original equation was limited to the highly concentrated equity group (which was the only significant group in the empirical test above), and the OC coefficient was 0.0435 , which was significant under the probability of $10 \%$. On the basis of these, a new control variable - the logarithm of the annual capital value of the enterprise is added. Since the enterprise performance is often closely related to its scale, this index is used to control the amount of enterprise resources and carrying capacity, and the regression result is still significant under the probability of 5\%.

(3) In the financing constraint mediating effect test (replace ROE with ROA), the corresponding A and B coefficients are highly significant, and both are positive, and the indirect influence is significant. The total effect coefficient value is 0.0572 and significant at $1 \%$ probability, so the two have a positive mediating effect. In the adjustment effect test, the enterprise performance index was changed to ROA, and the sample range of enterprises was controlled to be the total group and the equity dispersed group, respectively. The interaction coefficient of SA and OC was 0.078 and 0.099 , which were significant and verified the effectiveness of the adjustment effect.

The above results are consistent with the above results. Therefore, the research results are persuasive.

\section{V.3.4 The mechanism of equity concentration}

On the basis of previous studies, the structural equation model (SEM) was used to explore the influence mechanism of ownership concentration on corporate performance: ownership concentration has direct and indirect influence on corporate performance. Among them, the indirect path includes "corporate performance of free rider behavior of equity concentration" and "corporate performance of equity concentration operation efficiency", which successively reflect the "responsibility consciousness" and "supervision consciousness" of major shareholders. The fitting values of Table 9 and Table 10 were obtained by Amos24.0 software and maximum likelihood method. At the same time, the probability $\mathrm{P}$ value of chi-square statistics is 0.71 (a fitting standard greater than 0.05 ), that is, under the probability of $5 \%$, the Chi-square statistics is not significant, and there is no significant difference between the sample data and the theoretical model. For the set potential variables :(1) total asset turnover (TAT) and operating income growth rate (GRI) for "operating Efficiency", this path is simplified to OE (Operational Efficiency); (2) "Free Ride" is expressed by the number of senior executives (CEO) and the size of the board of directors, and the action path is simplified as FR (free-ride). The selected variables are used as the mediating variables for regression analysis, and the variable group of the original equation remains unchanged. According to the results in Table 9 and Table 10, the path coefficient of direct effect of ownership concentration on performance improvement is 0.027 , and the direct effect is significant at $1 \%$ of the probability, with the contribution reaching $85.05 \%$. Indirect effects mainly play a role through "inhibiting free-rider effect" and "improving operation efficiency", indicating that there are some mediating effects, reaching a total of $14.95 \%$.

According to the regression results :(1) from the perspective of corporate governance, equity concentration can strengthen the power and enterprise management of the controlling shareholders, simplify and optimize the organizational structure, make the management more seriously perform their duties, and reduce free-rider behavior. As can be seen from the regression coefficient in Table 9, the increase of ownership concentration can significantly reduce the size of CEO and board of directors, inhibit the psychology of "free rider", and enhance the sense of responsibility of management, but the mediating effect contribution rate is only $1 \%$. (2) Second, from the perspective of operational efficiency, under the trend of equity concentration, major shareholders, driven by the "sense of supervision", pay more attention to the 
operation and construction of enterprises, which will strengthen the professional division of labor and process optimization of management, improve the efficiency of income generation of assets, and enhance the operation ability. The contribution rate of this effect is $13.95 \%$, which plays a major role in the mediating effect. Thus it can be seen that driven by the "supervision consciousness" of major shareholders, it will be the main factor for the improvement of enterprise performance.

Table 9 Structural equation model (SEM) estimation results

\begin{tabular}{c|c|c|c|c|c}
\hline Effect of Path & Coefficient & Standard Error & Critical Ratio & P-Value & $\begin{array}{c}\text { Standardized } \\
\text { Coefficient }\end{array}$ \\
\hline OE $\leftarrow$ OC & 0.246 & 0.024 & 10.12 & 0.000 & 0.067 \\
\hline ROE $\leftarrow$ OE & 0.018 & 0.002 & 8.47 & 0.000 & 0.062 \\
\hline FR $\leftarrow$ OC & -0.159 & 0.017 & -9.39 & 0.000 & -0.067 \\
\hline ROE $\leftarrow$ FR & 0.002 & 0.003 & 2.68 & 0.011 & 0.005 \\
\hline ROE $\leftarrow$ OC & 0.027 & 0.007 & 3.68 & 0.000 & 0.025 \\
\hline
\end{tabular}

Table 10 Path decomposition of the equity trend of the largest shareholder affecting corporate performance

\begin{tabular}{c|c|c|c|c|c}
\hline \multirow{2}{*}{ Equity adjustment trend } & Paths Types & Influence Paths & Influential Effect & $\begin{array}{c}\text { Contribution } \\
\text { Degree }\end{array}$ & $\begin{array}{c}\text { Relative } \\
\text { Rate }\end{array}$ \\
\hline \multirow{3}{*}{$\begin{array}{c}\text { Ownership } \\
\text { Concentration }\end{array}$} & Direct & OC $\rightarrow$ ROE & 0.027 & 0.027 & $85.05 \%$ \\
\cline { 2 - 6 } & \multirow{2}{*}{ Indirect } & OC $\rightarrow \mathrm{FR} \rightarrow \mathrm{ROE}$ & $-0.159 * 0.002=-0.000318$ & 0.000318 & $1.00 \%$ \\
\cline { 3 - 6 } & & Sum $\rightarrow \mathrm{ROE}$ & $0.246 * 0.018=0.004428$ & 0.004428 & $13.95 \%$ \\
\cline { 2 - 6 } & Total & & 0.00411 & 0.004746 & $14.95 \%$ \\
\hline
\end{tabular}

Note: The contribution degree is the absolute influence of a certain path on the performance under the trend of concentration of shareholders' equity. It does not distinguish the direction.

\section{Conclusion and inspiration}

\section{VI.1 Main conclusion}

\section{VI.1.1 Financing constraints and equity concentration are negatively correlated}

If other conditions remain unchanged, the financing constraint is inversely proportional to the equity concentration degree, and the increase of equity concentration degree will effectively alleviate the financing constraint. This empirical result is corresponding to the conclusion of Means (2017). At the same time, it is found that this relationship is significant in the group with relatively concentrated and highly concentrated ownership, but not significant in the group with dispersed ownership.

Compared with the companies with dispersed equity, the willingness to pay cash dividends is usually higher in the sharehold-controlled companies, which can effectively alleviate the capital constraint problem of real estate institutions and obtain more attention and support from investors. If the largest shareholder holds a larger share, the supervision effect can be brought into play more effectively to reduce the "first class agency cost problem", trigger the "eyeball attraction effect" of enterprises to attract financing, relieve the situation of capital strain, and promote the maximization of shareholders' interests.

\section{VI.1.2 Concentration of equity is positively correlated with company performance}

Under the condition of fixed financing constraints, the increase of equity concentration degree can significantly improve enterprise performance. But in the group regression, only in the equity concentration group is obvious. If the shareholding share of the largest shareholder is low, according to the "moat defense 
effect", the increase of the largest shareholder's shareholding will significantly enhance the motivation and behavior of the minority shareholders to seize the interests and inhibit the benign development of the enterprise. When the largest shareholder is in the absolute controlling position, the higher control right can promote the managers to meet the shareholders' goals and improve productivity and financial performance to the greatest extent under the existing mechanism.

\section{VI.1.3 In the transmission process of equity concentration to corporate performance, financing constraints have significant regulatory and mediating effects}

The intermediation effect of financing constraint is mainly reflected in the state of absolute holding. The increase of ownership concentration will effectively alleviate financing constraints, "loosen" and "reduce pressure" for enterprise investment, investment, production and operation activities, and improve financial performance effectively. When the ownership concentration is not high enough, the mediating effect under financing constraints is difficult to emerge due to the inefficiency caused by "moat defense effect", "tunnel effect" and "first class agency problem".

In the regulatory role, the interaction between the financing constraint index SA and the ownership concentration degree OC can play a positive regulatory role, that is, the higher the degree of financing constraint, the lower the conduction effect. And it plays a significant role in the equity diversification group. In the state of relatively concentrated and highly concentrated equity, enterprises tend to have good execution efficiency, which can effectively alleviate financing constraints and improve performance, making financing constraints on its regulatory effect relatively small; In the case of decentralization of equity, minority shareholders are the main body, which plays a large role of restraining among shareholders, and the implementation and supervision effect of major shareholders is weak. In this case, the existence of financing constraints will further limit the play of its role.

\section{VI.2 Enterprise and industry management enlightenment}

\section{VI.2.1 Appropriately increase equity concentration to improve performance}

The relative concentration of equity has a good easing effect on the financing constraint of enterprises, which is conducive to raising capital, expanding operation and creating more income. In particular, the real estate industry is such a capital-intensive industry that the state should attach great importance to its negative impact on sustainable development caused by financing restrictions. The real estate agency should change the cost of the institution under the condition of "dispersed equity", increase the proportion of major shareholders appropriately, and change the proportion into "relatively concentrated" or "highly concentrated" equity, and give full play to the "supervision effect" and "incentive effect" of major shareholders.

In terms of equity concentration, the proportion of the largest shareholder should be controlled in the range of "20\% to $50 \% "$ or above $50 \%$, so as to exercise effective control over the enterprise and the management, ensure the good efficiency of the company's operation, and encourage the major shareholders to participate in the company's operation more actively. As for the specific range, the business performance, financing constraints, management system and so on should be considered comprehensively. When an enterprise is faced with certain financing constraints, it should change the state of equity decentralization and strengthen equity control, reduce internal friction caused by power struggle among shareholders and the hidden danger of "excessive control" by management in the original state, and improve decision-making efficiency to ensure the normal performance and value of the enterprise. Under the current financing constraints, real estate enterprises are faced with fierce market competition and must obtain sustained benefits to support their survival. Therefore, according to the research results, major shareholders of enterprises should maintain a medium-high degree of holding, and maintain the proportion of the largest shareholder close to or over $50 \%$, so as to reduce the incentive and marginal impact of major shareholders being misappropriated, and improve the performance of the institution directly or indirectly by providing financing constraints. 


\section{VI.2.2 Avoid "shareholders-hollowing out" to protect the interests of small and medium shareholders}

Moreover, the property sector needs to curb the "tunnelling effect" and the "moat effect". Within a certain proportion of shares, the motivation of major shareholders to encroach on property becomes stronger with the increase of shares. The corresponding enterprise management mechanism should be improved to effectively check and balance the rights of the largest shareholder, reduce the possibility of major shareholders' encroachment, limit their irrational behavior of cash dividends, and ensure the legitimate interests of minority shareholders to be protected and play a role in corporate governance. The government should also help set up a good ownership structure, improve the information disclosure of listed real estate companies, prevent enterprises from fighting for control, and improve coordination, so as to better cope with market changes.

\section{VI.3 Research contributions and shortcomings}

The innovation of this study is to compare the effect of equity structure adjustment on enterprises under different shareholding states, as well as the intermediary/regulatory effect of financing constraints in the transmission process, and to explore the influence mechanism of equity concentration inside enterprises on enterprise operation and financing. According to the characteristics of the real estate industry, consider the reasonable shareholding range of the largest shareholder, so as to provide useful reference for the academic circle.

Limited by the availability of data, it has not considered whether the financing constraints and corporate performance will be affected by geographical, national policies and other congenital conditions. How to reduce arbitrary decision-making errors and avoid corresponding risks in the first reasonable shareholding scope of real estate companies, especially in the case of medium and high shareholding? How to avoid "hollowing out" in the state of "weak holding" will be the next research direction.

\section{References}

[1]Abdelrazaq Farah Freihat, Ayda Farhan, Mohammed Shanikat. Do board of directors' characteristics influence firm performance? Evidence from the emerging market [J]. Journal of Management Information and Decision Sciences,2019,22(2).

[2]Almeida H, Campello M, Weisbach M S. The cash flow sensitivity of cash[J]. The Journal of Finance, 2004,59(4):1777-1804.

[3]Amp L Z, Amp S Z, Zhiwei W. Tunneling and Ownership Structure of a Firm:Evidence from Controlling Shareholder's Embezzlement of Listed Company's Funds in China[J]. Accounting Research, 2004.

[4]Chen-Lung, Chin, Yu-Ju, et al. International Diversification, Ownership Structure, Legal Origin, and Earnings Management: Evidence from Taiwan[J]. Journal of Accounting, Auditing \& Finance, 2009.

[5]Cho M H. Ownership structure, investment, and the corporate value: an empirical analysis[J]. Journal of Financial Economics, 1998, 47(1):103-121.

[6]Dasgupta S, Noe T H, Wang Z. Where did all the dollars go? The effect of cash flows on capital and asset structure[J]. Journal of Financial and Quantitative Analysis, 2011, 46(5): 1259-1294.

[7]David J. Denis and Diane K. Denis and Atulya Sarin. Ownership structure and top executive turnover[J]. Journal of Financial Economics, 1997.

[8]Deng Z, Hofman P S, Newman A. Ownership concentration and product innovation in Chinese private SMEs[J]. Asia Pacific Journal of Management, 2013, 30(3):717-734.

[9]Edwards D N, Pinkerton E. The hidden role of processors in an individual transferable quota fishery[J]. Ecology and Society, 2019, 24(3).

[10]Edwards D N, Pinkerton E. Priced out of ownership: quota leasing impacts on the financial performance 
of owner-operators[J]. Marine Policy, 2020, 111: 103718.

[11]Edwards J S, Weichenrieder A J. Ownership concentration and share valuation[J]. German Economic Review, 2004,5(2):143-171.

[12]Fazzari S M, Glenn H R, Petersen B C. Investment-Cash Flow Sensitivities Are Useful: A Comment On Kaplan And Zingales[J]. Quarterly Journal of Economics, 2000, 115(2):695-705.

[13]Florian Ielpo. Equity, credit and the business cycle[J]. Applied Financial Economics,2012,22(12).

[14]Kahn C, Winton A . Ownership Structure, Speculation, and Shareholder Intervention[J]. Journal of Finance, 1998, 53(1):99-129.

[15]Marco P, Röell Ailsa. The Choice of Stock Ownership Structure: Agency Costs, Monitoring, and the Decision to Go Public[J]. Quarterly Journal of Economics(1):187-225.

[16]Means G. The modern corporation and private property[M]. Routledge, 2017.

[17]Nguyen T, Locke S, Reddy K. Ownership concentration and corporate performance from a dynamic perspective: Does national governance quality matter?[J]. International Review of Financial Analysis, 2015, 41(OCT.):148-161.

[18]Safiullah M, Shamsuddin A. Risk in Islamic banking and corporate governance[J]. Pacific Basin Finance Journal, 2018, 47(FEB.):129-149.

[19]Slovin M B, Sushka M E. Ownership Concentration, Corporate Control Activity, and Firm Value: Evidence from the Death of Inside Blockholders[J]. The Journal of Finance, 2012, 48(4):1293-1321.

[20]Wruck K H. Equity ownership concentration and firm value: Evidence from private equity financings[J]. Journal of Financial economics, 1989,23(1):3-28.

[21]Wruck, Karen Hopper. Equity ownership concentration and firm value : Evidence from private equity financings[J]. Journal of Financial Economics, 2014, 23(4):3-28.

[22]Wruck K H, Wu Y L. Relationships, corporate governance, and performance: Evidence from private placements of common stock[J]. Journal of Corporate Finance, 2009, 15(1): 30-47.

[23]Wruck K H, Wu Y L. Equity incentives, disclosure quality, and stock liquidity risk[J]. Charles A. Dice Center Working Paper, 2017(2017-02). 